\title{
MODİFIYYE ATMOSFER (MA) PAKETLENMİŞ KIRLANGIÇ (Chelidonichthys lucerna Linnaeus, 1758) SOTENİN KALİTE ÖZELLİKLERİ
}

\author{
Bengünur Çorapc1 ${ }^{*}$, Demet Kocatepe \\ Sinop Üniversitesi, Su Ürünleri Fakültesi, Akliman, Sinop, Türkiye
}

Geliş / Received: 17.06.2019; Kabul / Accepted: 09.10.2019; Online bask1 / Published online: 06.11.2019

Çorapcı, B., Kocatepe, D. (2019). Modifiye atmosfer (MA) paketlenmiş kırlangıç (Chelidonichthys lucerna Linnaeus, 1758) sotenin kalite özellikleri. GIDA (2019) 44 (6): 1059-1070 doi: 10.15237/gida.GD19093.

Corapci, B., Kocatepe, D. (2019). The quality characteristics of tub gurnard (Chelidonichthys lucerna Linnaeus, 1758) saute packeaged with modified atmosphere (MA). GIDA (2019) 44 (6): 1059-1070 doi: 10.15237/gida.GD19093.

ÖZ

Bu çalşmada modifiye atmosfer (MA) paketlenmiş kırlangıç sotenin besin kompozisyonu, fiziksel, kimyasal, mikrobiyolojik özellikleri ve raf ömrü araştrrlmıştr. Sotenin protein, yăg, nem, kül, karbonhidrat ve enerji değerleri sirasiyla; $12.14 \mathrm{~g} / 100 \mathrm{~g}, 7.62 \mathrm{~g} / 100 \mathrm{~g}, \% 71.55, \% 2.56, \% 6.13$ ve $141.63 \mathrm{kcal} / 100 \mathrm{~g}$ olarak bulunmuştur. pH değeri depolama başı (0.gün) 6.28 , depolama sonu (20. gün) 7.36 olarak tespit edilmiştir. Su aktivitesi değerleri 20 günlük depolama boyunca 0.95 olarak ölçülmüştür (P>0.05). TBARS ve TVB-N değerleri 20 günlük depolama boyunca su ürünlerinde sınır değer olarak kabul edilen tüketilebilirlik değerlerini aşmamıştır. $L^{*}, a^{*}$ ve $b^{*}$ değerleri 20. gün sırasıyla; 67.62, 5.00, 25.31 olarak ölçülmüştür.

Sonuç olarak; $150^{\circ} \mathrm{C}$ 'de, toplamda $20 \mathrm{dk}$. süre ile pişirilen, $\% 60 \mathrm{CO}_{2} / \% 40 \mathrm{O}_{2}$ oranlarında MA ile paketlenen ve $+4 \pm 1^{\circ} \mathrm{C}$ 'de 20 gün depolamaya alınan kılçıksız kırlangıç balığı sotesinin tüketici için tavsiye edilebilir raf ömrü, spesifik bozulma bakterilerinin artşı göz önünde tutularak 16 gün olarak belirlenmiştir.

Anahtar kelimeler: Kırlangıç balığ1, sote, MA paketleme, raf ömrü

\section{THE QUALITY CHARACTERISTICS OF TUB GURNARD (Chelidonichthys lucerna Linnaeus, 1758) SAUTE PACKAGED WITH MODIFIED ATMOSPHERE (MA)}

\begin{abstract}
In this study, nutritional composition, physical, chemical, microbiological properties and shelf life of MA packaged tub gurnard saute were investigated. Protein, fat, moisture, ash, carbonhydrate and energy values of saute were found as $12.14 \mathrm{~g} / 100 \mathrm{~g}, 7.62 \mathrm{~g} / 100 \mathrm{~g}, 71.55 \%, 2.56 \%, 6.13 \%$ and 141.63 $\mathrm{kcal} / 100 \mathrm{~g}$, respectively. The $\mathrm{pH}$ value was 6.28 (day 0 ) and 7.36 at the end of storage (day 20). Water activity values were measured as 0.95 during storage time ( $P>0.05)$. TBARS and TVB-N values did not exceed the consumption limit values which admitted as limit values on seafoods during 20 days. $L^{*}, a^{*}$ and $b^{*}$ values were measured as $67.62,5.00,25.31$ (day 20). As a result, it was determined advisable shelf life of saute for consumer that cooked at $150^{\circ} \mathrm{C}$ for $20 \mathrm{~min}$, MA packaged ratios $\%$ $60 \mathrm{CO}_{2} / \% 40 \mathrm{O}_{2}$ and storaged at $+4 \pm 1^{\circ} \mathrm{C}$ during 20 day as 16 day when considering the increase of specific degradation bacteria.
\end{abstract}

Keywords: Tub gurnard, saute, modified atmosphere package, shelf life

\footnotetext{
${ }^{*}$ Yazışmalardan sorumlu yazar / Corresponding author

$\triangle$ : bengucorapci@hotmail.com 䟧 : (+90) 3682876265

岛: (+90) 3682876268
} 


\section{GİRIŞ}

Kırlangıç balıkları (Chelidonichthys lucernus, Linnaeus, 1758) Akdeniz, Karadeniz ve Doğu Atlantik okyanusu boyunca Norveç'ten Bat1 Afrika kıyılarına kadar dağılım gösteren demersal türlerdendir. Çoğunlukla kumlu, çamurlu ya da çakıllı dip sularında 20-300 m arasında değişen derinliklerde yaşarlar (Richards ve ark., 1990; İşmen ve ark., 2004). Kırlangıç balığı ile ilgili olarak yapılan çalışmalar incelendiğinde genel olarak; yaş, büyüme ve üreme durumlanının bölgesel olarak tespiti (İşmen ve ark., 2004; İlhan ve Toğulga, 2007; Boudaya ve ark., 2008; Mc Carthy ve Marriott, 2018) vücut büyüklüğü, cinsel olgunluk ve beslenme (Vallisneri ve ark., 2011), genetik ve morfolojisi (Uyan ve Turan, 2017) gibi konuların araştırıldığı görülmektedir. Bununla beraber, kırlangıç balığının kültür ortamında yetiştirilmesi üzerine yapılan çalışmalar mevcuttur (Polat ve Çakmak, 2012; Roncarati ve ark., 2013; Kerim ve ark., 2014; Roncarati ve ark., 2016).

MA paketleme, taze ya da minimal işlenmiş gidaların raf ömrünü uzatmak için kullanılmaktadır. Bunların dışında balık ve diğer su ürünleri gibi kolay bozulabilen ürünlerin raf ömrünün artırılmasında sıklıkla uygulanmaktadır (Ravi-Sankar et al., 2008; Masniyom, 2011). Su ürünlerinin paketlenmesinde kullanılan başlica gazlar $\mathrm{CO}_{2}, \mathrm{O}_{2}$ ve $\mathrm{N}_{2}$ gazlarıdır (Sivertsvik, 2002a). Balık ve su ürünlerinin paketlenmesinde en yaygın kullanilan gaz olan $\mathrm{CO}_{2}$ (Kirtil et al., 2016; Tsironi ve Taoukis, 2018) mikrobiyel gelişmeyi inhibe edici etkiye sahiptir. $\mathrm{CO}_{2}$ konsantrasyonlar1 mikrobiyal gelişmenin inhibisyonunda önemli bir rol oynar ve Pseudomonas spp. ve S. putrefaciens gibi organizmaların gelişimini geciktirmektedir (Sivertsvik, 2002a; Walsh and Kerry, 2012; Tsironi ve Taoukis, 2018). Kilıç balığ (X. gladius) (Giatrakou ve ark., 2008), kömür balı̆g1 (P. virens) (Lerfall ve ark., 2018), berlam balığ1 (M. merluccius) (Carrión-Granda ve ark., 2018) ve tilapya (O. niloticus) (Wang ve ark., 2019) filetolarının MA paketlendiği çeşitli çalışmalar mevcuttur.

Tüketime hazır ürünlere olan talep, günümüzde yaşam tarzı değişiklikleri ve tüketicilerin çabuk ve kolay hazırlanan gıdalara yönelmesiyle artmıştır. MA paketlenmiş tüketime hazır ürünlerin yüksek kalitelerini korumak için genellikle soğuk muhafaza koşulları korunarak dağıtımları sağlanmaktadır. $\mathrm{Bu}$ tip gidalarda depolama koşullarının tasarımı ve raf ömrünün artırılması için MA paketlemenin depolama üzerine etkilerinin anlaşılması önem taşımaktadır (Lee ve ark., 2008). Literatürde tüketime hazır istiridye (Costa ve ark., 2014), karides (Rutherford ve ark., 2007) ve kalamar halkalarının (Sanjua's-Rey, 2012) MA paketlendiği çalışmalara rastlanılmıştır. Bir başka çalışmada ise Speranza ve ark. (2009) pişirmeye hazır kolyoz ( $S$. japonicus), kırlangıç ( $T$. lucerna), berlam balı̆̆ (M. merluccius) ve mürekkep balığ1 (S. officinalis) 'nı MA paketlemiş, duyusal ve mikrobiyolojik kalite değișimlerini incelemişlerdir. Ancak kırlangıç balığının işlenmesi ve tüketime hazır hali ile ilgili herhangi bir çalışmaya rastlanmamıştır. Velioğlu ve ark., (2015)'in bildirdiği gibi, kırlangıç balığı hakkında literatürde çok fazla çalışma bulunmamaktadır.

Kırlangiç balığ1 ekonomik değeri yüksek, beyaz etli bir balık türüdür. Kültür ortamında yetiştiriciliğe uygun bir balık olması göz önünde bulundurulduğunda (Kerim ve ark., 2014), gelecek yıllarda işlenmesi ve pazara sunulması söz konusu olabilecektir. Bu durumda özellikle çorba, buğulama, ızgara gibi çeşitli şekillerde sevilerek tüketilen kırlangıç balığının su ürünleri işleme sektörüne katma değer sağlayacağ1 düşünülmektedir. Bu çalışmada; su ürünlerinin MA paketlenmesinde siklıkla kullanılan gaz oranları olan \% $60 \quad \mathrm{CO}_{2} / \% \quad 40 \quad \mathrm{O}_{2}$ kullanılmıs (Sivertsvik ve ark., 2002a), $\pm 4^{\circ} \mathrm{C}$ 'de depolanan tüketime hazır kıllangıç balığı sotesinin besin kompozisyonu ile kimyasal, fiziksel, mikrobiyolojik kalitesi ve raf ömrünün belirlenmesi amaçlanmıştır.

\section{MATERYAL VE YÖNTEM}

\section{Materyal}

Bu çalsşmada, Karadeniz'de (Sinop) 2018 yllında avlanmış ortalama boyları $41.73 \pm 0.51 \mathrm{~cm}$ ve ağırlıkları 752.91 $\pm 63.32 \mathrm{~g}$ olan kırlangıç balıkları kullanılmıştır. Balıklar, kırılmış buz içeren polistren balık kutusu ile laboratuvara getirilmiş, baş, iç organ temizliği yapılmış kırlangıç balıklarının kılçıksız filetosu çıkarılmıştır. Elde edilen filetolar yıkanmış ve suyu sızdırılmıştır. Toplamda yaklaşık $642 \mathrm{~g}$ fileto elde edilmiştir. 


\section{Kırlangıç Sotenin Hazırlanması}

Pişirme işlemi için $42 \times 13 \mathrm{~cm}$ kapaklı elektrikli bir pişirici (Arnica 409) kullanılmıştır. Kullanılan malzemelerden $\% 7.63$ soğan ve $\% 4.47$ biber, \% 3.27 sıvıyağ ve \% 5.01 tereyağında yaklaşık $5 \mathrm{dk}$. kavrulmuştur. Daha sonra \% 0.39 sarımsak ilave edilmiş ve $1 \mathrm{dk}$. kadar kavurmaya devam edilmiştir. Sırasıyla; \% 22.91 domates, \% 18.82 patates, \% 35.02 kırlangıç balığı ilave edilmiş ve bir süre daha pişirmeye bırakılmıştır. \% 0.43 karabiber, \% 0.43 tuz, \% 1.36 maydanoz ve \% 0.26 defne yaprağ ilavesinden sonra $2 \mathrm{dk}$. kadar pişirilmiştir. Pişirme işlemi $150^{\circ} \mathrm{C}$ 'de, toplamda 20 dk. süre ile gerçekleştirilmiştir.

\section{Paketleme ve Depolama}

Pişirme işleminden sonra kırlangıç sotenin oda sicaklığına kadar soğuması beklenmiştir. 30x21 $\mathrm{cm}$ ebatlarında paketlere $\left(\mathrm{O}_{2}\right.$ geçirgenliği 47.60 $\mathrm{mL} / \mathrm{m}^{2} /$ gün, nem geçirgenliği $3.48 \mathrm{~g} / \mathrm{m}^{2} /$ gün) ortalama $98.94 \pm 4.59 \mathrm{~g}$ olacak şekilde konulmuş ve ürün gaz oranı 1:3 olacak şekilde $\% 60 \mathrm{CO}_{2} / \%$ $40 \mathrm{O}_{2}$ oranlarında $\mathrm{MA}$ ile paketlenmiştir. Paketleme sonrası örnekler $+4 \pm 1^{\circ} \mathrm{C}$ 'de 20 gün depolamaya alınmıştır.

\section{Besin kompozisyonu analizleri}

Örneklerin protein miktarı Buchi SpeedDigester K-436 marka yakma ünitesi ve Buchi K-350 destilasyon cihazı kullanılarak, AOAC (1980a)'e göre belirlenmiştir. Ham yağ analizi AOAC (1980)'de belirtilen metot esas alınarak yarı otomatik Gerhardt marka yağ tayin cihazı ile gerçekleştirilmiştir. Kül tayini Protherm marka kül firını ile yapılmıştır (AOAC, 1980b). Nem miktarının tespiti Ludorf ve Meyer (1973)'e göre gerçekleştirilmiş, Nüve FN500 marka etüv kullanılmıştır. Karbonhidrat ve enerji değerlerinin belirlenmesi için Falch ve ark., (2010) metodu esas alınarak hesaplanmıştır. Besin kompozisyonu analizleri taze örnekte, depolama başı (0.gün) ve sonu (20. gün) olmak üzere 2 tekerrür, 3 paralel olarak gerçekleştirilmiştir.

\section{Kimyasal analizler}

Toplam Uçucu Bazik Azot miktarı Antonacopoulas tarafindan modifiye edilen Lucke and Geidel metoduna göre yapilmıştır (Hall, 1992). Tiyobarbitürik asit tayini ise Erkan ve ark. (2011)'e göre gerçekleştirilmiştir. Örnekler 2 tekerrür, 3 paralel şeklinde çalışılmıştır.

\section{Fiziksel analizler}

Örneklerin $\mathrm{pH}$ ölçümü $\mathrm{pH}$ metre (Werkstatten 82362, Weilheim) ile yapılmıştır. 1/10 oranında homojenize örnek/distile su cam baget yardımıla karıştırılmış daha sonra $\mathrm{pH}$ metrenin probu karışıma daldırılarak ölçüm gerçekleştirilmiştir. Su aktivitesi ölçümleri ise Novasina LabSwift su aktivitesi ölçüm cihazı kullanılarak AOAC (1980)'e göre belirlenmiştir. Renk ölçümleri için Konica Minolta/CR-A33a renk ölçüm cihazı kullanılmıştır. pH ve su aktivitesi örnekleri 2 tekerrür ve 2 paralel, renk ölçümleri ise 2 tekerrür 4 paralel şeklinde çalışılmıştır.

\section{Gaz ölçüm analizleri}

Paketlenen örneklerin paket içerisindeki gaz miktarını belirlemek için her analiz öncesinde gaz ölçümleri Witt Oxybaby, Germany marka gaz ölçüm cihazı ile gerçekleştirilmiştir.

\section{Mikrobiyolojik analizler}

Paket içi gaz ölçümünden sonra, paket yüzeyi \% 70 'lik etil alkolle silinmiş ve steril spatula yardımı ile steril kaplar içerisine laminer kabin içerisinde $10 \mathrm{~g}$ örnek alınmıştır. Örnekler $90 \mathrm{~mL}$ pepton çözeltisi içerisinde seyreltilmiş ve ardından 10${ }^{1}$.....10-6 oranlarındaki dilüsyonlara $0.1 \mathrm{~mL}$ ekim yapılmıştır. Anaerob bakteri ekimi için ise $10 \mathrm{~g}$ balık eti ayrilarak $90 \mathrm{~mL} \% 0.1$ Pepton from casein, \% 0.05 Cystein chloride monohydrate, \% $0.85 \mathrm{NaCI}$ içeren seyreltme çözeltisinden dilüsyonlar hazırlanmıştır.

Toplam mezofil aerob ve psikrofil bakteri sayımı AOAC (2000)'a göre; toplam mezofil anaerob bakteri, toplam Koliform, Toplam maya küf, E. coli ve Staphylococcus aures sayımı Halkman (2005)'e göre; laktik asit bakterileri ve $\mathrm{H}_{2} \mathrm{~S}$ üreten bakteriler (Shewenella putrefaciens dâhil) Ravi Sankar vd. (2008) ile Kostaki ve ark., (2009)'a göre; laktik asit bakterileri ve Brochotrix thermosphacta Stamatis ve Arkoudelos (2007)'e göre yapılmıştır. Tüm mikrobiyolojik analizler 2 tekerrür 2 paralel olarak uygulanmış ve sonuçlar log $\mathrm{kob} / \mathrm{g}$ olarak verilmiştir. 


\section{İstatistik analizler}

Tüm veriler $\% \quad 95$ güven aralığında değerlendirilmiş olup, istatistik analizler (Varyans analizleri ve Tukey testleri) Minitab Versiyon 17.0.2 ile gerçekleştirilmiştir.

\section{BULGULAR VE TARTIŞMA}

\section{Besin kompozisyonu}

Çalışmada kullanılan kırlangıç balığının ham protein, ham yağ, ham kül, nem ve enerji değerleri ile MA paketlenmiş tüketime hazır kırlangıç sotenin deneme başı ve deneme sonu verileri Çizelge 1'de verilmiştir. Karadeniz'den Mayıs ayında avlanan doğal kırlangıç balığının ham protein, ham yağ, ham kül ve nem içeriği sırasıyla; $\% 16.46, \% 0.85, \% 1.76$ ve $\% 77.46$ olarak tespit edilmiştir. Küçükgülmez ve ark. (2010) Kuzeydoğu Akdeniz kiylarından bahar mevsiminde avlanan $C$. lucernus' un ham protein, ham yağ, ham kül ve nem içeriğini sirasıyla; \% $19.50, \% \quad 0.26, \% 1.35$ ve $\% 78.34$ olarak bildirmişlerdir. Aynı çalışmada kırlangıç balığının besin kompozisyonu kış ve bahar aylarında da incelenmiş ve en düşük yağ içeriği bahar aylarında tespit edilmiştir. Ersoy (2006) Kuzeydoğu Akdeniz'den avlanan kırlangıç balığının ham protein içeriğini mayıs ayında \% 20.04, ham yağ içeriğini ise $\% \quad 0.24$ olarak bildirmiştir. Çalısmamızdan görüldüğü gibi Karadeniz'den aynı mevsimde avlanan balığın yağ oranı daha yüksektir. Özoğul ve ark. (2007) çalışmamızda kullandığımız kırlangıç balığının farklı bir türü olan T. lucerna'nın ham yağ içeğini \% 1.59 olarak bildirmektedir. Kırlangıç balığı "az yağlı" bir balıktır. \% 0.5'den az yağ içeren balıklar "yağsız", $\%$ 0.5-2 oranında yağ içeren balıklar "yarı-yağlı", $\%$ 2'den fazla yağ içeren balıklar ise "yağlı" balık olarak sinıflandırılmaktadır (Clucas ve Ward 1996). Çalışmamızda kırlangıç balığı Karadeniz'den avlanan çarpan balığından (Kaya ve Kocatepe 2014) daha yüksek oranda protein ve yağ içerirken; hamsi, çinekop, barbun gibi balıklardan daha fazla miktarda protein içermektedir. Bununla beraber, bu balıklara kıyasla oldukça az oranda yăg içermektedir (Kocatepe ve Turan 2012). Çiğ kırlangıç balığının enerji içeriği $87.39 \mathrm{kcal}$ olarak hesaplanmış olup, bu değer Karadeniz'den avlanan yağlı balıklara kıyasla oldukça düşüktür. Kırlangıç balığının enerji içeriği Karadeniz'den avlanan çarpan balı̆̆1 ile (82.84 Kcal) (Kocatepe ve ark. 2012) ile benzerlik göstermektedir.

Çizelge 1. Kurlangiç balığ1 sotesine ait besin kompozisyonu analiz sonuçları Table 1. Nutrient composition analysis results of tub gurnard saute

\begin{tabular}{|c|c|c|c|c|c|c|}
\hline $\begin{array}{l}\text { Depolama } \\
\text { süresi } \\
\text { (günler) } \\
\text { Storage time } \\
\text { (days) }\end{array}$ & $\begin{array}{c}\text { Ham } \\
\text { protein } \\
\text { Crude protein } \\
(\mathrm{g} / 100 \mathrm{~g})\end{array}$ & $\begin{array}{l}\text { Ham yağ } \\
\text { Crude fat } \\
\text { (g/100g) }\end{array}$ & $\begin{array}{l}\text { Nem } \\
\text { Moisture } \\
(\%)\end{array}$ & $\begin{array}{l}\text { Ham kül } \\
\text { Crude ash } \\
\quad(\%)\end{array}$ & $\begin{array}{c}\text { Karbonhidrat } \\
\text { Carbobydrate } \\
(\%)\end{array}$ & $\begin{array}{c}\text { Enerji } \\
\text { Energy } \\
\text { (kcal/100g) }\end{array}$ \\
\hline $\begin{array}{l}\text { Çiğ } \\
\text { (Raw) }\end{array}$ & $16.46 \pm 0.11^{\mathrm{a}}$ & $0.85 \pm 0.06^{c}$ & $77.46 \pm 0.12^{\mathrm{a}}$ & $1.76 \pm 0.10^{\mathrm{b}}$ & $3.48 \pm 0.20^{\mathrm{b}}$ & $87.39 \pm 0.31^{\mathrm{c}}$ \\
\hline 0 & $12.14 \pm 0.28^{b}$ & $7.62 \pm 0.33^{b}$ & $71.55 \pm 0.09 \mathrm{c}$ & $2.56 \pm 0.06^{a}$ & $6.13 \pm 0.27^{a}$ & $141.63 \pm 2.16^{b}$ \\
\hline 20 & $13.49 \pm 0.54^{\mathrm{b}}$ & $9.65 \pm 0.06^{a}$ & $73.28 \pm 0.11^{b}$ & $1.83 \pm 0.05^{b}$ & $1.75 \pm 0.53^{c}$ & $147.77 \pm 0.76^{a}$ \\
\hline
\end{tabular}

\pm Standart hata. Aynı sütunda günler arasındaki farklı harfler istatistiksel açıdan önemlidir $(P<0.05)$.

\pm Standard error. Different letters between days are statistically significant in the same column. $(P<0.05)$.

Kırlangıç balığının pişirilme sürecinde içine eklenen katkılar ürünün ham protein ve nem içeriğinde düşüşe sebep olurken, ham yağ ve ham kül miktarında oransal olarak artış gözlenmiştir. Balığa eklenen sıv1 yă̆ ve tereyağı ham yağ içeriğinde artışa sebep olmuştur. Pişirme işlemi ile ürün nem kaybetmiştir. Karbonhidrat değeri pişirme ile artmış ancak depolamanın son günü azalmıştır $(\mathrm{P}<0.05)$. Sote kırlangıç yemeğinin enerji içeriği $141.63 \mathrm{kcal} / 100 \mathrm{~g}$ olarak hesaplanmış olup, ürünün bir porsiyonu $(200 \mathrm{~g})$ yaklaşı 283 kcal'dir. MA paketlenerek 20 gün süresince buzdolabı koşullarında saklanan ürünün, depolama süresi sonundaki ham protein içeriğinde istatistik olarak önemsiz bir artış gözlenmiştir ( $\mathrm{P}>0.05)$. Paketlenmiş ürünün 0 . 
güne klyasla nem içeriği ve ham yağ içeriği artmıştır $(\mathrm{P}<0.05)$. $\mathrm{CO}_{2}$ 'nin suda ve yağda çözünürlüğü fazladır; sıcaklık düşüşü ile birlikte $\mathrm{CO}_{2}$ 'in suda çözünürlüğü artar (Jay 2000); ve karbonik asit oluşur (Sivertsvik ve ark. 2002b). Çalışmamızda MA paketlenmiş sote kırlangıç yemeğinin nem içeriğindeki artışı sebebi zamanla $\mathrm{CO}_{2}$ çözünmesinin artmasından kaynaklanabilir.

\section{Fiziksel ve kimyasal analizler}

MA paketlenmiş kırlangıç sotesinin depolama süresince paket içi gaz oranları, $\mathrm{pH}$, su aktivitesi,
TBARS ve TVB-N değerleri Çizelge 2'de verilmiştir. Kırlangıç sotenin paket içi karbondioksit $\left(\mathrm{CO}_{2}\right)$ oranının depolama süresince azaldığ1 görülmüştür. Depolama başında (0. gün) $\%$ 49.20 1.00 olan $\mathrm{CO}_{2}$ değeri, depolamanın son gününde (20. gün) $\% \quad 10.05 \pm 2.45$ olarak ölçülmüsstür. $\mathrm{Bu}$ durumun karbondioksitin, karbonik asidin artışıyla ilgili olarak kas içerisinde sıv1 formda çözülmesiyle meydana gelmiş olabileceği söylenebilir (Banks ve ark., 1980; Masniyom, 2011).

Çizelge 2. Kırlangıç balığı sotesine ait fiziksel ve kimyasal analiz sonuçları

Table 2. Physical and chemical analysis results of tub gurnard saute

\begin{tabular}{|c|c|c|c|c|c|}
\hline $\begin{array}{l}\text { Depolama } \\
\text { süresi } \\
\text { (günler) } \\
\text { Storage time } \\
\text { (days) }\end{array}$ & $\begin{array}{c}\text { Paket içi } \mathrm{CO}_{2} \\
\text { Oranı }(\%) \\
\text { Ratio of } \mathrm{CO}_{2} \text { in } \\
\text { package }(\%)\end{array}$ & $\begin{array}{l}\mathrm{pH} \\
\mathrm{pH}\end{array}$ & $\begin{array}{l}\text { Su aktivitesi } \\
\text { Water activity }\end{array}$ & $\begin{array}{c}\text { TBARS } \\
(\mu \mathrm{g} \mathrm{MDA} / \mathrm{g}) \\
\text { TBARS } \\
(\mu g \mathrm{MD} A / g)\end{array}$ & $\begin{array}{c}\text { TVB-N } \\
(\mathrm{mg} / 100 \mathrm{~g}) \\
\text { TVB-N } \\
(\mathrm{mg} / 100 \mathrm{~g})\end{array}$ \\
\hline Çiğ & & $7.45 \pm 0.07^{a}$ & $0.94 \pm 0.00^{\mathrm{b}}$ & $0.71 \pm 0.01^{\mathrm{c}}$ & $14.87 \pm 0.10^{\mathrm{bc}}$ \\
\hline 0 & $49.20 \pm 1.00^{a}$ & $6.28 \pm 0.01^{c}$ & $0.95 \pm 0.00^{\mathrm{b}}$ & $1.74 \pm 0.04 \mathrm{bc}$ & $9.79 \pm 0.06^{c}$ \\
\hline 4 & $33.85 \pm 3.95^{\mathrm{ab}}$ & $6.07 \pm 0.03^{\mathrm{d}}$ & $0.95 \pm 0.00^{\mathrm{b}}$ & $2.38 \pm 0.24 \mathrm{ab}$ & $21.24 \pm 0.00^{\mathrm{ab}}$ \\
\hline 8 & $21.20 \pm 2.90^{\mathrm{bc}}$ & $6.27 \pm 0.04^{\mathrm{cd}}$ & $0.95 \pm 0.00^{\mathrm{b}}$ & $2.98 \pm 0.16^{\mathrm{a}}$ & $21.96 \pm 0.28^{\mathrm{ab}}$ \\
\hline 12 & $15.90 \pm 3.40^{c}$ & $6.54 \pm 0.07 \mathrm{c}$ & $0.95 \pm 0.00^{\mathrm{b}}$ & $2.43 \pm 0.10^{\mathrm{ab}}$ & $20.53 \pm 0.88^{\mathrm{ab}}$ \\
\hline 16 & $10.40 \pm 2.70^{c}$ & $7.00 \pm 0.10^{\mathrm{b}}$ & $0.95 \pm 0.00^{\mathrm{b}}$ & $1.78 \pm 0.12^{\mathrm{b}}$ & $23.57 \pm 3.19^{a}$ \\
\hline 20 & $10.05 \pm 2.45^{c}$ & $7.36 \pm 0.07 \mathrm{a}$ & $0.95 \pm 0.00^{\mathrm{b}}$ & $2.14 \pm 0.19 \mathrm{~b}$ & $26.18 \pm 1.32^{a}$ \\
\hline
\end{tabular}

\pm Standart hata. Aynı sütunda günler arasındaki farklı harfler istatistiksel açıdan önemlidir $(P<0.05)$.

\pm Standard error. Different letters between days are statistically significant in the same column. $(P<0.05)$.

Çiğ kırlangiç balığına ait $\mathrm{pH}$ değeri $7.45 \pm 0.07$ olarak ölçülmüş olup, bu değer kırlangiç sotesinde 0 . günde $6.28 \pm 0.01$ değerine düşmüştür. Depolamanin 4. gününden itibaren ise yükselmeye başlamış ve 20. günde $7.36 \pm 0.07$ olarak tespit edilmiştir. Karbondioksitin üründe bulunan suda çözünerek karbonik asit oluşumu ile pH'yı düşürdüğü bildirilmiştir (Siverstik, 2002a). Paketlemeden sonra görülen $\mathrm{pH}$ düşüşünün bu durum ile ilgili olduğu söylenebilir. Depolamanın 12. gününden sonra yükselmeye başlayan $\mathrm{pH}$ değerleri ise tazeliğin kaybolduğunun bir belirtisi sayılabilir (Şengör ve ark., 2000). Lerfall ve ark., (2018) taze kömür balı̆̆1 (P. virens)'nın pH değerini 7.00 olarak bildirmişler ve MA ile paketlenen balığın $\mathrm{pH}$ değerinin depolama süresince farklı MA gazlarından önemli derecede etkilendiğini bildirmişlerdir. Su aktivitesi değeri çiğ kırlangıç balığında $0.94 \pm 0.00$ olarak ölçülmüş, bu değer kırlangıç sotede 20 günlük depolama süresince $0.95 \pm 0.00$ değerinde sabit kalmıştır $(\mathrm{P}>0.05)$.

TBARS değerindeki artış, esas olarak enzimatik hidroliz ve otooksidasyon ile ilgilidir (Halldorsdottir ve ark., 2013) ve $\mathrm{O}_{2}$ içeriğinin otooksidasyonu etkilediği bildirilmiştir (Zhu ve ark., 2018). Çiğ kırlangıç balı̆ı̆ının TBARS değeri $0.71 \pm 0.01 \mu \mathrm{g} \quad \mathrm{MDA} / \mathrm{g}$ olarak belirlenmiştir. Kırlangıç sotenin 0 . günü bu değer $1.74 \pm 0.04 \mu \mathrm{g}$ $\mathrm{MDA} / \mathrm{g}$ olarak ölçülmüş, depolamanın son günü (20.gün) ise $2.14 \pm 0.19 \mu \mathrm{g} \mathrm{MDA} / \mathrm{g}$ 'a yükselmiştir. Ancak su ürünlerinde tüketilebilirlik sınır değeri olan 7-8 mg MDA/kg (Varllk ve ark., 1993) değerini aşmamıştır. 
Bununla beraber; TBARS değerlerinin depolama süresince MDA, aminoasitler, proteinler, glikoz ve diğer balık bileşenleri arasındaki çeşitli etkileşimler nedeniyle gerçek yağ oksidasyonu oranını temsil etmediği bildirilmiştir (Fernandez ve ark., 1997; Giatrakou ve ark., 2008). Bu anlamda çalışmamızda sote yapımında kullandığımız sebze ve baharat içeriklerinin TBARS değerlerini etkilemiş olduğu söylenebilir. Giatrakou ve ark., (2008) kekik esansiyel yağı ve MA paketleme ile çeşitli şekillerde paketledikleri kılıç balığının, aerobik ortamda, MA paketleme ve buz içerisinde 18 gün depolamışlardır. Buna göre; grupların TBARS değerlerinin değişken olduğu ve paketleme işlemine bakılmaksızın spesifik bir belirleyici olmadığını ifade etmişlerdir. Sanjua' sRey ve ark. (2012) keklik otu ve kekik esansiyel yağlarını tüketime hazır kalamar halkalarına uygulayıp, MA ile paketlemişlerdir. Buna göre; $+4^{\circ} \mathrm{C}$ 'de 14 gün depolanan kalamar halkalarının TBARS değerlerinin tüm gruplarda oldukça düşük olduğu bildirilmiştir.

Kırlangıç balığının TVB-N değeri $14.87 \pm 0.10$ $\mathrm{mg} / 100 \mathrm{~g}$ olarak ölçülmüsstür. Kırlangiç sotenin 0 . günü bu değer $9.79 \pm 0.06 \mathrm{mg} / 100$ g’a düşmüş ve depolamanın 20. günü $26.18 \pm 1.32 \mathrm{mg} / 100 \mathrm{~g}$ 'a yükselmiştir. Su ürünlerinde tazelik ve tüketilebilirlik durumuna göre TVB-N değeri açısından (Varlık ve ark., 1993) kırlangıç sotenin kalitesini değerlendirdiğimizde depolamanın 20. günü ürünün 'iyi' kalitede olduğu söylenebilir.

Kaba ve ark., (2013) çalışmamızla benzer içeriğe sahip alabalıktan elde edilen kokoreci plastik kaplarda (MA kullanmadan) $+4^{\circ} \mathrm{C}^{\prime} \mathrm{de}$ depolamışlardır. Duyusal olarak bozulmanın gerçekleştiği depolamanın 5. gününde ürünün TVB-N değeri $24.10 \mathrm{mg} / 100 \mathrm{~g}$ olarak bildirilmiştir. $\mathrm{Bu}$ değer çalışmamızda MA ile paketlenen kırlangıç sotenin 20. gün TVB-N değerine yakın bulunmuştur.

TVB-N değerinin hızlı yükselmesinin, mikrobiyel yükün artışının bir göstergesi olduğu bildirilmiştir (Özoğul ve ark., 2004). Çalışmamızda 4, 16 ve 20. gün TVB-N ve mikrobiyolojik değerler incelendiğinde özellikle toplam bakteri yükünün TVB-N ile paralel bir şekilde artış gösterdiği görülmektedir.

Kırlangiç balığı sotesine ait renk analizi sonucu elde edilen $L^{*}, a^{*}$ ve $b^{*}$ değerleri Çizelge 3 'te verilmiştir. Çiğ kırlangıç balığına ait $L^{*}, a^{*}$ ve $b^{*}$ değerleri sirasiyla $61.36 \pm 0.25, \quad 3.85 \pm 0.11$ ve $6.42 \pm 0.09$ olarak ölçülmüştür. Kırlangıç soteye ait 0 . gün değerleri ise sirasiyla; $70.71 \pm 0.75$, $5.57 \pm 0.61$ ve $23.55 \pm 0.74$ olarak belirlenmiştir. 20 günlük depolama süresince ürünün renk değerlerinin $L^{*} 65.90 \pm 1.33-70.78 \pm 1.33$ arasinda, $a^{*} \quad 5.00 \pm 0.28-8.08 \pm 0.25$ arasinda ve $b^{*}$ 23.31 $\pm 1.01-25.31 \pm 0.91$ arasında değişim gösterdiği gözlenmiştir. Literatürde MA ile paketlenmiş çeşitli balık türlerine ait renk değerlerinin incelendiği çalışmalar (Zhu ve ark., 2018; Wang ve ark., 2019) mevcuttur. Ancak çalışmamızda kırlangıç balığına ek olarak çeşitli sebze ve baharat katk1ları kullanilarak elde edilen sotenin renk değerlendirmesinin kıyaslanabileceği çalışmalara rastlanmamışır. $\mathrm{Bu}$ nedenle elde edilen verilerin gelecekte yapilacak benzer çalışmalara katkı sağlayacağı düşünülmektedir.

Çizelge 3. Kırlangıç balığı sotesine ait renk ( $\left.L^{*}, a^{*}, b^{*}\right)$ analiz sonuçları

Table 3. Color ( $\left.L^{*}, a^{*}, b^{*}\right)$ analysis results of tub gurnard saute

\begin{tabular}{lccc}
\hline & $L^{*}$ & $a^{*}$ & $b^{*}$ \\
\hline $\begin{array}{l}\text { Çiğ } \\
\text { Raw }\end{array}$ & $61.36 \pm 0.25^{\mathrm{c}}$ & $3.85 \pm 0.11^{\mathrm{b}}$ & $6.42 \pm 0.09^{\mathrm{b}}$ \\
\hline 0 & $70.71 \pm 0.75^{\mathrm{a}}$ & $5.57 \pm 0.61^{\mathrm{ab}}$ & $23.55 \pm 0.74^{\mathrm{a}}$ \\
\hline 4 & $69.73 \pm 1.60^{\mathrm{ab}}$ & $6.14 \pm 0.72^{\mathrm{ab}}$ & $23.38 \pm 0.63^{\mathrm{a}}$ \\
\hline 8 & $68.67 \pm 0.37^{\mathrm{ab}}$ & $5.80 \pm 0.76^{\mathrm{ab}}$ & $24.50 \pm 0.32^{\mathrm{a}}$ \\
\hline 12 & $65.90 \pm 1.33^{\mathrm{bc}}$ & $8.08 \pm 0.25^{\mathrm{a}}$ & $24.49 \pm 0.91^{\mathrm{a}}$ \\
\hline 16 & $70.78 \pm 1.33^{\mathrm{a}}$ & $5.26 \pm 0.77^{\mathrm{b}}$ & $23.31 \pm 1.01^{\mathrm{a}}$ \\
\hline 20 & $67.62 \pm 0.85^{\mathrm{ab}}$ & $5.00 \pm 0.28^{\mathrm{b}}$ & $25.31 \pm 0.91^{\mathrm{a}}$ \\
\hline
\end{tabular}

\pm Standart hata. Aynı sütunda günler arasındaki farklı harfler istatistiksel açıdan önemlidir $(P<0.05)$.

\pm Standard error. Different letters between days are statistically significant in the same column. $(P<0.05)$. 


\section{Mikrobiyolojik analizler}

Su ürünlerinde bozulmalar fiziksel, kimyasal ve mikrobiyolojik olarak gerçekleşir. Özellikle balıktaki fiziksel değişiklikler deneyimli panelistlerce kolayca anlaşılabilir. Avlanma anında başlayan bozulma çevresel faktörlerinde etkisi ile hızlanır. Özellikle mikrobiyolojik bozulma üzerine balığın başlangıç mikroorganizma yükü ve cinsi, av zamanı, bölge, suyun kirlilik durumu, av metodu ve av araçları, muhafaza koşulları, transfer koşulları ve işleme yöntemleri etkilidir (Jayasinghe ve Rajakaruna 2005).

Çiğ kırlangıç balı̆̆ı ve MA paketlenmiş kırlangıç balığının depolama süresince toplam mezofil ve psikrofil aerob, toplam maya küf, toplam koliform, B. thermosphacta ve $\mathrm{H}_{2} \mathrm{~S}$ üreten ( $S$. putrefaciens dabil) mikroorganizmalara ait veriler Çizelge 4'te verilmiştir. Çĭg kırlangıç balığının TMAB, TPAB, TMK, TKB, BrT, ve $\mathrm{H}_{2} \mathrm{~S}$ üreten bakteri sayıları sirasiyla; $3.48 \log \mathrm{kob} / \mathrm{g},<1 \log$ $\mathrm{kob} / \mathrm{g}, 2.55 \log \mathrm{kob} / \mathrm{g}, 2.35 \log \mathrm{kob} / \mathrm{g}, 3.44 \log$ $\mathrm{kob} / \mathrm{g}$ ve $<1 \mathrm{log} \mathrm{kob} / \mathrm{g}$ olarak tespit edilmiştir. Çiğ kırlangıç balığının mikroflorasında baskın türlerin $\mathrm{BrT}>\mathrm{TMK}>\mathrm{TKB}$ olduğu söylenebilir.

Çiğ balık etinin TMAB bakteri yükü uygulanan 1sıl işlem ile birlikte $1.96 \mathrm{log} \mathrm{kob} / \mathrm{g}$ düşmüştür $(\mathrm{P}<0.05)$. MA paketleme işlemi ile birlikte kırlangıç sotenin TMAB yükü 12. güne kadar istatiksel açıdan değişmemiştir $(\mathrm{P}<0.05)$. Paketlemede kullanilan $\mathrm{CO}_{2}$ gazi aerob bakteri gelişimini baskılamıştır. 12. günden itibaren ise TMAB yükü artmaya başlamış, 20. günde ise maksimum değere ulaşmış̧ır (5.64 log kob/g). Benzer şekilde psikrofil aerob bakteri yükü pişirme işlemi ile birlikte < 1 log kob/g'a düşmüş, ardindan zamanla artarak deneme sonunda 4.91 $\log$ kob/g’a ulaşmışır. Pek çok araştırmacı tarafindan $\mathrm{CO}_{2}$ miktarının bakteri gelişimini inhibe ettiği bildirilmiştir (Turan ve Kocatepe 2013; Kocatepe ve ark. 2016; Lerfall ve ark., 2018). Benzer şekilde çalışmamızda da hem mezofil hem de psikrofil aerob bakteri gelişimi yavaştır. Toplam bakteri sayıs $>6-7 \mathrm{log} \mathrm{kob} / \mathrm{g}$ değerine ulaştı̆̆ında, su ürünlerinde bozulmanın başlayabileceği bildirilmiştir (Poli ve ark. 2006).
Çiğ kırlangıç balı̆̆ının başlangıç toplam maya-küf sayıs $2.55 \log \mathrm{kob} / \mathrm{g}$ iken pişirme ile bu değer 1.96 $\log$ kob/g'a kadar düşmüş 12. güne kadar da istatistiksel olarak önemli bir artış olmamışıtır $(\mathrm{P}>0.05)$. Depolamanin sonunda kadar TMK sayısı 4 log kob/g'1 aşmamıştır.

Koliform grubu bakteriler balıkların solungaç ve bağırsaklarında bulunabilen bakteri türleridir ve 1sıl işlemle inaktif hale gelirler. Çĭğ kırlangıcın başlangıç TKB sayısı $2.35 \mathrm{log} \mathrm{kob} / \mathrm{g}$ iken pişirme işleminin etkisi ile $<1 \mathrm{log} \mathrm{kob} / \mathrm{g}$ 'a düşmüş, 20. güne kadar da artış olmamıştır ( $\mathrm{P}>0.05)$.

BrT’nin gelişebilmesi için en uygun $\mathrm{pH}$ aralığ 5-9 pH'dır (Anonim 2010a). Çalışma başında çiğ kırlangıç balığı florasında bulunan BrT isıl işlem ve eklenen katkıların pH'yı düşürmesine bağlı olarak $1 \log \mathrm{kob} / \mathrm{g}^{\prime} \mathbf{n}$ altına düşmüştür. 12. günden itibaren ise artış göstererek depolama süresi sonunda 4.03 log kob/g'a ulaşmıştır.

Kırlang1ç sotenin yapıldığ1 ilk günde ve MA depolamasını izleyen süreçte $\mathrm{H}_{2} \mathrm{~S}$ üreten bakteriler 12. güne kadar oldukça düşük seviyelerdeyken 12 . günden itibaren artış göstermiş ancak $2.50 \mathrm{log}$ kob/g'1 geçmemiştir. Adams ve Moss (2008) soğukta saklanan balıklarda dominant bakteri türlerinin $S$. putrefaciens gibi psikrofil gram negatif çubuk bakteriler olduğunu bildirmektedir. Gidalarin duyusal bozulma noktasinda, bozulmada rol oynayan ancak istenmeyen değişikliklere sebep olmayan mikroorganizmaların oluşturduğu mikroflora Gram ve ark. (2002) tarafindan spesifik bozulma organizmas1 (lar1) (Specific Spoilage Organism(s)SSO) olarak adlandırılmıştır. Shewanella, Lactobacillus, Brochothrix, Enterobacter, Staphylococcus gibi mikroorganizma cinsleri taze ve bozulmuş su ürünlerinde bulunan SSO'lar arasinda bulunur (Jay 2000; Nollet ve Toldra 2009). Çalışmamızda BrT çiğ kırlangıç etinde $3.44 \log \mathrm{kob} / \mathrm{g}$ düzeyinde tespit edilmiş ancak MA paketlenmiş ürünün 12 . gününe kadar 1 log kob/g'ın altında kalmıştır. Depolama süresi sonunda da $4.03 \mathrm{log} \mathrm{kob} / \mathrm{g}$ tespit edilmiştir. Çalışmamızda da olduğu gibi Nollet ve Toldra (2009)'da özellikle MA paketlenerek soğukta muhafaza edilen ürünlerde BrT bakterilerinin zamanla arttığını belirtmiştir. 
SSO’lar dişında ESO olarak adlandırılan Geçici Bozulma Organizmaları (Ephemeral Spoilage Organism) da ürünlerin taşıma, işleme ve depolama aşamalarına bağlı olarak ortaya çıkarlar (Anonim 2010b). Nollet ve Toldra (2009) MA paketlenen ürünlerdeki spesifik ESO'lar arasında Laktik asit bakterileri ve BrT'nin yer aldığını bildirmiştir. Ancak çalışma süresince hem çiğ üründe hem de MA paketlenen üründe laktik asit bakterileri tespit edilememiştir. Benzer şekilde Françoise (2010) MAP uygulanarak paketlenen su ürünlerinde laktik asit bakterilerinin bozulma üzerine çok etkili olmadığını özellikle marine balık, tuzlu balık ya da soğuk dumanlanmış balık vb. gibi ürünlerde etkili olduğunu vurgulamıştır.

Çalışma süresince hem çiğ kırlangıç balığında hem de MA paketlenmiş ürünlerde TAB, E. coli ve $S$. aureus tespit edilememiştir.

Tüm mikrobiyolojik analiz sonuçları incelendiğinde MA paketlenmiş kırlangıç balığının 20 günlük depolama süresi boyunca gözlemlenen spesifik organizma türlerinden en baskınının $B$. thermosphacta, ardindan toplam maya küf ve $\mathrm{H}_{2} \mathrm{~S}$ üreten bakteriler ( $S$. putrefaciens dahil) olduğu gözlenmiştir.

Çizelge 4. Kırlangıç balığı sotesine ait mikrobiyolojik analiz sonuçları (log kob/g)

Table 4. Microbiological analysis results of tub gurnard saute (log cfu/g)

\begin{tabular}{lcccccc}
\hline & TMAB & TPAB & TMK & TKB & BrT & $\begin{array}{c}H_{2} \text { S üreten } \\
\text { bakteriler* }\end{array}$ \\
\hline $\begin{array}{l}\text { Çiğ } \\
\text { Raw }\end{array}$ & $3.48 \pm 0.44^{\mathrm{bc}}$ & $<1 \pm 0.00^{\mathrm{e}}$ & $2.55 \pm 0.11^{\mathrm{c}}$ & $2.35 \pm 0.09^{\mathrm{a}}$ & $3.44 \pm 0.07^{\mathrm{b}}$ & $<1 \pm 0.00^{\mathrm{c}}$ \\
\hline 0 & $1.96 \pm 0.00^{\mathrm{d}}$ & $<1 \pm 0.00^{\mathrm{e}}$ & $1.96 \pm 0.00^{\mathrm{d}}$ & $<1 \pm 0.00^{\mathrm{c}}$ & $<1 \pm 0.00^{\mathrm{c}}$ & $<1 \pm 0.00^{\mathrm{c}}$ \\
\hline 4 & $2.35 \pm 0.09^{\mathrm{d}}$ & $2.26 \pm 0.00^{\mathrm{d}}$ & $1.96 \pm 0.00^{\mathrm{d}}$ & $<1 \pm 0.00^{\mathrm{c}}$ & $<1 \pm 0.00^{\mathrm{c}}$ & $<1 \pm 0.00^{\mathrm{c}}$ \\
\hline 8 & $2.66 \pm 0.00^{\mathrm{cd}}$ & $2.86 \pm 0.05^{\mathrm{c}}$ & $2.11 \pm 0.15^{\mathrm{d}}$ & $<1 \pm 0.00^{\mathrm{c}}$ & $<1 \pm 0.00^{\mathrm{c}}$ & $<1 \pm 0.00^{\mathrm{c}}$ \\
\hline 12 & $3.69 \pm 0.02^{\mathrm{b}}$ & $3.19 \pm 0.09^{\mathrm{b}}$ & $3.31 \pm 0.03^{\mathrm{b}}$ & $<1 \pm 0.00^{\mathrm{c}}$ & $3.29 \pm 0.10^{\mathrm{b}}$ & $2.35 \pm 0.09^{\mathrm{ab}}$ \\
\hline 16 & $4.18 \pm 0.04^{\mathrm{b}}$ & $3.37 \pm 0.05^{\mathrm{b}}$ & $3.65 \pm 0.03^{\mathrm{ab}}$ & $<1 \pm 0.00^{\mathrm{c}}$ & $3.99 \pm 0.02^{\mathrm{a}}$ & $2.26 \pm 0.00^{\mathrm{b}}$ \\
\hline 20 & $5.64 \pm 0.03^{\mathrm{a}}$ & $4.91 \pm 0.01^{\mathrm{a}}$ & $3.91 \pm 0.00^{\mathrm{a}}$ & $1.96 \pm 0.00^{\mathrm{b}}$ & $4.03 \pm 0.06^{\mathrm{a}}$ & $2.50 \pm 0.06^{\mathrm{a}}$ \\
\hline
\end{tabular}

\pm Standart hata. Aynı sütunda günler arasındaki farklı harfler istatistiksel açıdan önemlidir $(P<0.05)$.

\pm Standard error. Different letters between days are statistically significant in the same column. $(P<0.05)$.

*TMAB: Toplam mezofilik aerobik bakteri, Total mesophilic aerobic bacteria; TPAB: Toplam psikrofilik aerobik bakteri, Total psychrophilic aerobic bakteria; TMK: Toplam maya- küf, Total yeast-mold; TKB: Toplam koliform bakteri, Total coliform bacteria; TAB: Toplam anaerobik bakteri, Total anaerobic bacteria; E. coli: Eschericbia coli; S. aureus: Staphylococcus aureus; BrT: B. thermosphacta; ${ }^{*} H_{2} S$ üreten bakteriler (S. putrefaciens dâhil).

\section{SONUÇ}

$\mathrm{Su}$ ürünleri mikrobiyal kontaminasyona karşı oldukça hassas gidalardır. Yüksek nem içerikleri ve düşük bağ doku miktarları nedeniyle hızlıca bozulan su ürünlerinin raf ömrünü artırmak amaciyla pek çok yöntem denenmektedir. Son yıllarda artan hizlı ve hazır gida tüketim alışkanlıkları ile birlikte hayatımıza giren MA paketleme teknolojisi, su ürünlerinde çiğ ve pişmiş ürünlerde uygulanmaktadır. Çalışmamızda ise kırlangıç balığına ilk kez tüketime hazır "isıt-ye MA paketleme kırlangıç sote" olarak uygulanan bu yöntem yenilik arz etmektedir. Çalsşma süresince yapılan tüm analizler dikkate alındığında kırlangıç balığının yüksek protein düşük yağ içeriği ile diyet bir besin kaynağı olduğu, MA paketlenen "1sit-ye kırlangıç sotenin" tüketici için tavsiye edilebilir raf ömrü, SSO’ların artısı göz önünde tutularak 16 gün olarak önerilebilir.

\section{KAYNAKLAR}

Adams, M.R., Moss, M.O. (2008). Food Microbiology. RSC Publishing. 463s. ISBN: 978-085404-284-5.

Anonim (2010a). http://www.arrowscientific. com.au/Brochothrix_thermospHacta.html.

(Erişim tarihi: 22 Haziran 2010). 
Anonim (2010b). http: //www.meatims.org/symposium_proceeding.pdf. 18p. (Erişim tarihi: 22 Haziran 2010).

AOAC (1980). Official Methods of Analysis. In: Horwitz W, editor. Animal Feed. 13 $3^{\text {th }}$ ed. USA; $125 \mathrm{pp}$.

AOAC (1980a). Official Methods of Analysis. In: Horwitz W, editor. Animal Feed. 13 $3^{\text {th }}$ ed. USA; $125 \mathrm{pp}$.

AOAC (1980b). Official Methods of Analysis. In: Horwitz W, editor. Animal Feed. 13 $3^{\text {th }}$ ed. USA; $125 \mathrm{pp}$.

AOAC (2000). Official Methods of Analysis. 17th Ed. Association of Official Analytical Chemists. Gaithersburg, USA.

Banks, H., Nickelson, R., Finne, G. (1980). Shelf life studies on carbon dioxide packaged finfish from the Gulf of Mexico. J. Food Sci., 45:157-162, doi:10.1111/j.1365-2621.1980.tb02566.x.

Boudaya, L., Neifar, L., Rizzo, P., Badalucco, C. Bouain A., Fiorentino, F. (2008). Growth and reproduction of Chelidonichtbys lucerna (Linnaeus) (Pisces: Triglidae) in the Gulf of Gabe`s, Tunisia J. Appl. Ichthyol., 24:581-588, doi:10.1111/j.14390426.2008.01095.x.

Carrión-Granda, X., Fernández-Pan, I., Rovira , J., Maté, J. I. (2018). Effect of antimicrobial edible coatings and modified atmosphere packaging on the microbiological quality of cold stored hake (M. merluccius) fillets. Hindawi Journal of Food Quality. doi:10.1155/2018/6194906.

Clucas, I.J., Ward, A.R. (1996). Post-harvest fisheries development: a guide to handling, preservation, processing and quality. Natural Resources Institute. $353 \mathrm{~s}$. ISBN:0-85954-441-9.

Costa, C., Conte, A., Del Nobile, M.A. (2014). Effective preservation techniques to prolong the shelf life of ready-to-eat oysters. J Sci Food Agric., 94(13): 2661-2667, doi: 10.1002/jsfa.6605.

Erkan, N., Üretener, G., Alpas, H., Selcuk, A., Özden, Ö., Buzrul, S. (2011). Effect of high hydrostatic pressure (HHP) treatment on physicochemical properties of horse mackerel $(T$. trachurus). Food Bioprocess Technol., 4(7):1322-1329, doi: 10.1007/s11947-010-0415-4.

Ersoy, B. (2006). Kuzeydoğu Akdeniz (Adana/Karataş) bölgesinde avlanma mevsiminde tüketilen balıkların besin kompozisyonu ve ağır metal içerikleri. Çukurova Üniversitesi Fen Bilimleri Enstitüsü Su Ürünleri Anabilim Dalı Doktora Tezi, Adana, Türkiye, 155 s.

Falch, E., Overrien, I., Solberg, C., Slizyte, R. (2010). Composition and calories. In: Seafood and seafood product analysis, Nollet, LML and Toldrá, F.,eds, CRC Press, Florida. pp. 257-288.

Fernandez, J., Perez-Alvarez, I.A., FernandezLopez, J.A. (1997). Thiobarbituric acid test for monitoring lipid oxidation inmeat. Food Chem., 59(3):345-53, doi:10.1016/S0308-8146(96) 00114-8.

Françoise, L. (2010). Occurence and role of lactic acid bacteria in seafood products. Food Microbiol., 27(6): 698-709, doi: 10.1016/j.fm.2010.05.016.

Giatrakou, V., Kykkidou, S., Papavergou, A., Kontominas, M.G., Savvaidis, I.N. (2008). Potential of oregano essential oil and MAP to extend the shelf life of fresh swordfish: A comparative study with ice storage. J. Food Sci., 73(4):167-173, doi: $\quad 10.1111 /$ j.17503841.2008.00729.x.

Gram L., Ravn, L., Rasch, M., Bruhn, J.B., Christensen, A.B., Givskov, M. (2002). Food spoilage-interactions between food spoilage bacteria. Int J Food Microbiol., 78(1-2):79-97, doi:10.1016/S0168-1605(02)00233-7.

Hall, GM. (1992). Fish Processing Technology. Blackie Academic Professional, New York, USA. ISBN: 978-1-4613-1113-3.

Halldorsdottir, S. M., Kristinsson, H. G., Sveinsdottir, H., Thorkelsson, G., Hamaguchi, P. Y. (2013). The effect of natural antioxidants on haemoglobin-mediated lipid oxidation during enzymatic hydrolysis of cod protein. Food Chem., 141(2):914-919, doi: 10.1016/j.foodchem. 2013.03.101. 
Halkman, A.K. (2005). Gida Mikrobiyolojisi ve Uygulamalar1, Ankara Üniversitesi. 358 s. ISBN:975-00373-0-8.

İlhan Uçkun, D., Toğulga, M. (2007). Age, growth and reproduction of tub gurnard Chelidonichthys lucernus Linnaeus, 1758 (Osteichthtyes: Triglidae) from İzmir Bay, Aegean Sea, Eastern Mediterranean. Acta adriat., 48(2): 173 - 184.

İşmen, A., İşmen, P., Başusta, N. (2004). Age, Growth and reproduction of tub gurnard (Chelidonichthys lucerna L. 1758) in the Bay of İskenderun in the Eastern Mediterranean. Turk $J$ Vet Anim Sci., 28, 289-295.

Jay, J.M. (2000). Food preservation with modified atmospheres. In: Modern Food Microbiology, Aspen publishers, pp 283-300.

Jayasinghe, P.S., Rajakaruna, R.M.A.G.G. (2005). Bacterial contamination of fish soldin fish markets in the central province of Sri Lanka, J. Natn. Sci. Foundation Sri Lanka, 33(3):219-221, doi:10.4038/jnsfsr.v33i3.2328.

Kaba, N., Çorapc1, B. Eryaşar, K. (2013). Production of kokoreç from rainbow trout (Oncorbynchus mykiss, Walbaum 1792) and determination of shelf life. BIB AD, 6(2): 6-10.

Kaya Y., Kocatepe D. (2014). Chemical compositon and nutritional quality of scorpion fish (Scorpaena porcus, Linnaeus 1758) muscle. Indian Journal of Anim. Research., 48(1):83-87, doi:10.5958/j.0976-0555.48.1.018.

Kerim, M., Ayvaz, B., Kaya, D., Ustaoğlu Tirıl, S., Baki, B. (2014). Kırlangıç balığ1 (Chelidonichthys lucerna L., 1758)'nin kültür ortamina adaptasyonu üzerine bir çalışma. İstanbul Üniversitesi Su Ürünleri Dergisi, 29(1):14-20.

Kirtil, E., Kilercioğlu, M., Oztop, M. H. (2016). Modified Atmosphere Packaging of Foods. In: Reference Module in Food Sciences. Elsevier. Amsterdam, Netherlands: ISBN: 9780081005965.

Kocatepe D., Turan H. (2012). Proximate and fatty acid composition of some commercially important fish species from the Sinop region of the Black Sea. Lipids. 47(6):635-641, doi: 10.1007/s11745-012-3658-1.
Kocatepe, D., Turan, H., Altan C.O., Keskin İ., Ceylan A. (2016). Effect of modified atmosphere packaging on the shelf life of rainbow trout (Oncorbynchus mykiss, Walbaum 1792) mince. Food Sci. Technol. Int., 22(4):343-352, doi: 10.1177/1082013215601771.

Kostaki, M., Giatrakou, V., Savvaidis, I.N., Kontominas, M.G. (2009). Combined effect of MAP and thyme essential oil on the microbiological, chemical and sensory attributes of organically aquacultured sea bass (Dicentrarchus labrax) fillets. Food Microbiol., 26(5):475-482, doi: 10.1016/j.fm.2009.02.008.

Küçükgülmez A., Çelik M., Ersoy B., Yanar Y. (2010). Effects of season on proximate and fatty acid compositions of two mediterranean fish-the round herrig (E. teres) and tub gurnard (C. lucernus). J. Food Sci. Technol.. 45(5):1056-1060, doi:10.1111/j.1365-2621.2010.02237.x.

Lee, K.E., Kim, H.J., An, D.S., Eun Soon Lyu, E.S., Lee, D.S. (2008). Effectiveness of modified atmosphere packaging in preserving a prepared ready-to-eat food. Packag. Technol. Sci., 21(7): 417423, doi:10.1002/pts.821.

Lerfall, J., Thomassen, G.M.B., Jakobsen, A.N. (2018). Quality of fresh saithe (P. virens) in modified atmosphere packages as affected by the gas composition. Food Packaging and Shelf Life, 18(4): 147-156, doi:10.1016/j.fpsl.2018.11.006.

Ludorf, W., Meyer, V. (1973). Fishe und fisherzeuge. Z.Auflage. Verlag Paul Parey In Berlin und Hamburg; pp. 209-210.

Masniyom, P. (2011). Deterioration and shelf-life extension of fish and fishery products by modified atmosphere packaging. Songklanakarin J. Sci. Technol., 33 (2):181-192.

McCarthy, I.D., Marriott, A.L. (2018). Age, growth and maturity of tub gurnard $(C$. lucerna Linnaeus 1758; Triglidae) in the inshore coastal waters of Northwest Wales, UK. J Appl Ichthyol,, 34(3):581-589, doi: 10.1111/jai.13614.

Nollet, L.M.L., Toldrá, F. (2009). Handbook of seafood and seafood product analysis. CRC Press. Taylor\& Francies Group. Boca Raton. New York, 928 p. ISBN: 13: 978-1420046335. 
Özoğul, F., Polat, A., Özoğul, Y. (2004). The effects of modified atmosphere packaging and vacuum packaging on chemical, sensory and microbiological changes of sardines (S. pilchardus). Food Chem., 85(1):49-57, doi:10.1016/j.foodchem.2003.05.006.

Özoğul Y., Özoğul F., Alagöz S. (2007). Fatty acid profiles and fat contents of commecially important seawater and freshwater fish species of Turkey: A comparitive study. Food Chem., 103(1):217-223, doi:10.1016/j.foodchem. 2006.08.009.

Polat, H., Çakmak, E. (2012). Kültür şartlarına adapte edilen kırlangıç balığı (C. lucerna Linnaeus, 1758)'ndan döl alım1. Yunus Arastrma Bülteni, (4):1-5, doi:10.17693/yunusae.v2012i21907. 235428 .

Poli, M. B., Messini, A., Parisi, G., Scappini, F., Vigiani, V., Giorgi, G., Vincenzini, M. (2006). Sensory, pshysical, chemical and microbiological changes in European sea bass (D. labrax) fillets packed under modified atmosphere/air of prepared from whole fish stored in ice. Int J Food Sci Technol., 41(4):444-454, doi:10.1111/j.13652621.2005.01094.x.

Ravi-Sankar, C.N., Lalitha, K.V., Jose, L., Manju, S. and Gopal, T.K.S. (2008). Effect of packaging atmosphere on the microbial attributes of pearlspot (E. Suratensis, Bloch) stored at $0-2^{\circ} \mathrm{C}$. Food Microbiol., 25(3):518- 528, doi:10.1016/j.fm.2007.12.003.

Richards, W.J., Saksena, V.P. (1990). Triglidae. In: Check-List of the Fishes of the Eastern Tropical Atlantic (CLOFETA). Quero, J. C., Hureau, J. C., Karrer, C.A.P., Saldanha, L. (Eds). JNICT, Lisbon: SEI, Paris and UNESCO, Paris, (2):680-684.

Roncarati, A. Mariotti, F. Felici, A. Meligrana M. Melotti P. (2016). Suitability of artisanal fishery discards as feed for juvenile tub gurnard (C. lucerna L.) reared in sea bottom cages in the mid Adriatic Sea. Medit. Mar. Sci., 17(3): 644-650, doi:10.12681/mms.1750.

Roncarati, A., D'Andrea, M., Pilla, F., Felici, A., Melotti, P. (2013). Tub gurnard Chelidonichthys lucerna L.: a new fish species suitable for farming? First answers evaluating the growth of juveniles reared at different stocking densities, welfare and fillet quality. Aquaculture Research, 44:1140-1151, doi:10.1111/j.1365-2109.2012.03238.x.

Rutherford,T.J., Marshall, D.L., Andrews, L.S., Coggins, P.C., Schilling, M.W., Gerard, P. (2007). Combined effect of packaging atmosphere and storage temperature on growth of Listeria monocytogenes on ready-to-eat shrimp. Food Microbiol., 24(7-8): 703-710, doi: 10.1016/j.fm.2007.03.011.

Sanjua's-Rey, M., Pourashouri, P., Velazquez, J.B., Aubourg, S.P. (2012). Effect of oregano and thyme essential oils on the microbiological and chemical quality of refrigerated $\left(4^{\circ} \mathrm{C}\right)$ ready-to-eat squid rings. Int J Food Sci Technol., 47(7): 1439_ 1447, doi:10.1111/j.1365-2621.2012.02991.x.

Sivertsvik, M., Jeksrud, W.K., Rosnes, J.T. (2002a). A review of modified atmosphere packaging of fish and fishery productsSignificance of microbial growth, activities and safety. Int. J. Food Sci. Tecbnol., 37(2):107-127, doi:10.1046/j.1365-2621.2002.00548.x.

Sivertsvik, M., Rosnes, J.T., Bergslien, H. (2002b). Modified atmosphere packaging. In: Minimal Processing Technologies in the Food Industry, Ohlsson, T., Bengtsson, N. (ed.). CRC Press, Boston, New York Washington, DC, pp 61-86.

Speranza, B., Corbo, M.R., Conte, A. Sinigaglia, M., Del Nobile, M.A. (2009). Microbiological and sensorial quality assessment of ready-to-cook seafood products packaged under modified atmosphere. J Food Sci., 74(9):473-478, doi: 10.1111/j.1750-3841.2009.01369.x.

Stamatis, N., Arkoudelos, S.J. (2007). Quality asessment of Scomber colias japonicus under modified atmosphere and vaccum packaging. Food Control, 18(4):292-300, doi:10.1016/j.foodcont.2005.10.009.

Şengör, G.F., Çelik, U., Akkuş, S. (2000). Buzdolabı koşullarında depolanan istavrit balığ1 (T. trachurus, L. 1758)'nin tazeliginin ve kimyasal bileşiminin belirlenmesi. Turk J Vet Anim Sci., 24(3):187-193.

Tsironi, T.N., Taoukis, P.S. (2018). Current practice and innovations in fish packaging. $J$ 
Aquat Food Prod T., 27(10):1024-1047, doi:10.1080/10498850.2018.1532479.

Turan H., Kocatepe D. (2013). Different MAP conditions to improve the shelf life of sea bass. Food Sci Biotechnol., 22(6):1589-1599, doi:10.1007/s10068-13-0255-x.

Uyan, A, Turan, C. (2017). Genetic and morphological analyses of tub gurnard C. lucerna populations in Turkish marine waters. Biochem. Syst. Ecol., 73:35-40, doi:10.1016/j.bse. 2017.06.003.

Vallisneri, M., Stagioni, M., Montanini, S., Tommasini, S. (2011). Body size, sexual maturity and diet in C. lucerna (Osteichthyes: Triglidae) from the Adriatic Sea, north eastern Mediterranean. Acta adriat., 51(1): $141-148$.

Varlık, C., Ugur, M., Gokoglu, N., Gun, H. (1993). Su ürünlerinde kalite kontrol ilke ve yöntemleri. Gida Teknolojisi Derneği Yayın No: 17, Ayrınt1 Matbaas1, Ankara. 174s.

Velioğlu, H.M., Tümay Temiz H., Boyac1, İ.H. (2015). Differentiation of fresh and frozen- thawed fish samples using Raman spectroscopy coupled with chemometric analysis. Food Chem., 172:283-290, doi:10.1016/j.foodchem. 2014.09.073.

Walsh, H., Kerry, J. P. (2012). Packaging of readyto-serve and retail-ready meat, poultry and seafood products. In: Advances in Meat, Poultry and Seafood Packaging. Kerry, J. P., (Ed.) Cambridge, UK: Woodhead Publishing, pp 406-436.

Wang, Z.C., Yan, Y., Fang, Z., Nisar, T., Sun, L., Guo, Y. Xia, N., Wang, H., Chen, D.W. (2019). Application of nitric oxide in modified atmosphere packaging of tilapia (O. niloticus) fillets. Food Control, 98:209-215, doi:10.1016/j.foodcont.2018.11.043.

Zhu, Z., Gao, H., Gao, T., Sun, D.W. (2018). Quality comparison of grass carp and salmon fillets packaged in modified atmosphere with different composite films. J Food Process Eng., doi: 10.1111/jfpe.12803. 